\title{
Improving Student Attitudes toward Discussion Boards Using a Brief Motivational Intervention
}

Virginia Clinton

University of North Dakota, virginia.clinton@und.edu

Alison E. Kelly

University of North Dakota, alison.e.kelly@und.edu

How does access to this work benefit you? Let us know!

Follow this and additional works at: https://commons.und.edu/ehb-fac

\section{Recommended Citation}

Virginia Clinton and Alison E. Kelly. "Improving Student Attitudes toward Discussion Boards Using a Brief Motivational Intervention" (2019). Education, Health \& Behavior Studies Faculty Publications. 41.

https://commons.und.edu/ehb-fac/41

This Article is brought to you for free and open access by the Department of Education, Health \& Behavior Studies at UND Scholarly Commons. It has been accepted for inclusion in Education, Health \& Behavior Studies Faculty Publications by an authorized administrator of UND Scholarly Commons. For more information, please contact und.commons@library.und.edu. 
Running Head: DISCUSSION BOARDS

Improving Student Attitudes toward Discussion Boards Using a Brief Motivational Intervention Virginia Clinton and Alison E. Kelly

University of North Dakota

Author's note. Virginia Clinton is an Assistant Professor in Educational Foundations and Research at the University of North Dakota. Alison Kelly is an Assistant Professor in Psychology at the University of North Dakota.

Correspondence concerning this article should be addressed to Virginia Clinton, (701) 777-5793, virginia.clinton@und.edu, or 231 Centennial Dr., Grand Forks, ND, 58202, USA. Her orcid identifier is orcid.org/0000-0002-4705-2217 and follow on Twitter at @v_e_clinton. 
(C) 2019, American Psychological Association. This paper is not the copy of record and may not exactly replicate the final, authoritative version of the article. Please do not copy or cite without authors' permission. The final article will be available, upon publication, via its DOI: $10.1037 /$ stl0000160 
Clinton, V., \& Kelly, A.E. (in-press). Improving student attitudes toward discussion boards using a brief motivational intervention. Scholarship of Teaching and Learning in Psychology. doi: $10.1037 /$ st10000160 


\begin{abstract}
Discussion boards are tools to afford student interaction and engagement in online courses, but students often have negative attitudes toward discussion boards. The purpose of this study was to determine whether an intervention informing students of the usefulness of online discussion boards affected their attitudes toward discussion boards. The instructor randomly assigned students $(N=65)$ to view a video and answer an essay question on either the benefits of discussion boards (treatment) or how discussion boards were graded (control). Students in the treatment condition indicated discussion boards as being more useful than did students in the control condition, $p=.04$, Cohen's $d=.53$, but there were no reliable differences in terms of how inherently interesting and enjoyable discussion boards were, $p=.07$, Cohen's $d=.44$. Additionally, students reported their perceptions of the value (benefits) and costs (disadvantages) of discussion boards in open-ended items. There were no effects of the intervention on student grades on the discussion boards or exams ( $p=.87$, Cohen's $d=.02$ and $p=.88$, Cohen's $d=$ $.08)$, but perceived utility and intrinsic value of discussion boards correlated with exam grades $(r$ $=.26, p=.04$ and $r=.33, p=.01)$. Overall, the study provides an effective intervention for improving student attitudes toward discussion boards.
\end{abstract}

Keywords: online discussion; online motivation; asynchronous discussion; discussion boards 
Improving Student Attitudes toward Discussion Boards Using a Brief Motivational Intervention

The number of postsecondary students taking courses online, in which all course material is accessed and engaged with electronically, has increased considerably (Ortagus, 2017). Online education provides flexibility and convenience as well as opportunities for prospective students who are constrained geographically (Johnson \& Palmer, 2015; Ortagus, 2018). Discussion boards, which are asynchronous web-based forums for students to post about the course and comment on peers' posts, provide an opportunity to interact with other students about the content (Poll, Widen, \& Weller, 2014; Uijl, Filius, \& Ten Cate, 2017). However, students often have negative perceptions of discussion boards and consider them inferior to face-to-face discussions (Jaggars \& Xu, 2016; Majid, Idio, Liang, \& Zhang, 2015). The purpose of this study is to test the effectiveness of an intervention to improve student attitudes toward discussion boards.

\section{Discussion Boards Background}

There are numerous benefits to discussion boards that support their use in online courses. Online students often report feeling isolated in their courses and feel a lack of social presence, typically measured through self-reports, as students' ability to interact with their learning community online is limited (Liu, Gomez, \& Yen, 2009). Social presence is an important consideration as it predicts overall performance in online courses (Joksimovic, Gaševic, Kovanovic, Riecke, \& Hatala, 2015; Rockinson-Szapkiw, Wednt, Wighting, \& Nisbet, 2016). The opportunity for student-student interaction afforded by discussion boards may increase feelings of social presence in online courses (Cho \& Tobias, 2016). Indeed, researchers have measured social presence by examining student-to-student interactions in discussion boards, including continuing threads, complimenting, expressing appreciation, and asking questions (Joksimovic, Gaševic, Kovanovic, Riecke, \& Hatala, 2015). Moreover, there is evidence that discussion boards may help students better understand the course content (see Aloni \& Harrington, 2018, for a review). This is because the opportunities for interactivity provided by discussion boards could promote better comprehension through developing and sharing ideas about the content (Kent, Laslo, \& Rafaeli, 2016). This could explain why one study found students who were able to collaborate with other students in an online courses achieved higher grades than those who worked individually (Kurucay \& Inan, 2017). Students who are active on discussion boards earn better grades on average than their less-active peers (Green, Farchione, Hughes, \& Chan, 2014; Kent et al., 2016; Wei, Peng, \& Chou, 2015). Moreover, being involved 
in discussion boards may help students who are at risk of failing online courses improve their grades (Davies \& Graff, 2005). Indeed, one study found that the use of online group discussions, along with other active learning techniques, yielded better grades than lecture alone (Gayman, Hammonds, \& Rost, 2018).

Despite the benefits of discussion boards, students often have a negative perception of them (Kauffman, 2015). Some students report that they do not see the purpose of interacting with peers in discussion boards (Jaggars \& Xu, 2016) and one study found that nearly half of students perceived that they did not learn in discussion boards (Dennen, 2008). Another issue is that students tend to prefer face-to-face discussions over online asynchronous ones (Hurt, Moss, Bradly, Larson, \& Lovelace, 2012). In studies, students have reported a dislike of discussion boards because of the lack of immediate feedback (Majid et al., 2015) and that discussion boards were more awkward and less enjoyable than face-to-face discussions (Hurt et al., 2012). In addition, students have reported that discussion boards were less efficient than face-to-face discussions and lack the opportunities for nonverbal communication and immediate clarification that face-to-face discussions had.

Beyond the student complaints specific to discussion boards, there is also evidence of student resistance to active learning. Active learning is a pedagogical approach in which students interact with material and peers to promote critical thinking (Shekhar, Prince, Finelli, Demonbrun, \& Waters, 2018). Discussion boards would be considered a type of active learning and some students express resistance or dislike of active learning techniques instead preferring to passively listen to lectures (Clinton \& Kelly, in-press; Lobo, 2017; Tsang \& Harris, 2016; Zayac $\&$ Paulk, 2014). For examples, students report that learning from peers is less efficient and more prone to inaccuracy than learning directly from the instructor (Clinton \& Wilson, in-press). However, research findings of student attitudes toward active learning have been mixed. In the findings of some studies, students prefer active learning through peer interaction over direct instruction from the professor (Daouk, Bahous, \& Bacha, 2016; Gayman et al., 2018; Saville \& Zinn, 2006; see Querol, Rosales, \& Soldner, 2015, for a review). A thorough examination for the different findings by study on student attitudes toward active learning is beyond the scope of this manuscript, but could be due to differences in student expectations for what learning should involve, how effectively active learning is structured, and students' previous experiences with active learning (Nguyen et al., 2017). Nevertheless, it is important to note that in studies in which 
a preference for active learning was found, there were usually some students who indicated a dislike of active learning (e.g., Finelli et al., 2018). Overcoming this resistance and promoting positive attitudes toward discussion boards is critical given that there is an association between

positive attitudes towards discussion boards and yielding benefits from discussion boards (DietzUhler \& Lanter, 2012).

\section{Theoretical Background}

One approach to improving student attitudes is grounded in the expectancy-value theory of motivation. In this theory, one's perceived value of a task is key for motivation to complete the task (Wigfield \& Eccles, 2000). Perceived value consists of two key components: utility value and intrinsic value (Eccles \& Wigfield, 2002; Eccles et al., 1983). Utility value is derived from the degree of usefulness of a task or how much a task connects to personal life (Hulleman, Durik, Schwegert, \& Harackiewicz, 2008; Hulleman, Kosovich, Barron, \& Daniel, 2017). For example, the utility value of a biology course could include learning how the content opens up career opportunities or how a person could use the knowledge to improve home gardens. In contrast, intrinsic value is based on how much one finds something intriguing or enjoyable (Eccles \& Wigfield, 2002). The intrinsic value of a biology course could be that the material is intellectually stimulating or the lectures are interesting.

One aspect of expectancy-value theory that motivation scholars have developed in recent years is cost (Barron \& Hulleman, 2015). Cost consists of multiple undesirable components of a task, such as what one must give up and the effort involved to engage in a task, as well as the negative emotions that may result from a task (Eccles, 2005). If the cost of a task is perceived to be excessive, students are likely to avoid the task even if that task has high value (Jiang, Rosenzweig, \& Gaspard, 2018). For example, a student may value a biology course highly, but opt to take the course if the costs of time and money for tuition and materials are too high. Cost is important for instructors to be aware of, as reducing cost can enhance motivation (Flake, Barron, Hyllmena, McCoach, \& Welsh, 2015).

Researchers have designed interventions grounded in expectancy-value theory to increase students' perceived utility value (i.e., utility-value interventions; e.g., Harackiewicz, Canning, Tibbets, Priniski, \& Hyde, 2016; Hulleman \& Harackiwicz, 2009; Hulleman et al., 2017). In utility-value interventions, students generally learn about how the course content is useful for their goals and/or connects to their personal lives (Hulleman \& Harackiewicz, 2009; Hulleman, 
Godes, Hendricks, \& Harackiewicz, 2010). Outside influences are more likely to affect utility value than intrinsic value, thus, interventions typically aim to alter perceived utility value rather than intrinsic value (Harackiewicz et al., 2016). These interventions have generally been effective at increasing student motivation (Lazowski \& Hulleman, 2016). Previous utility-value interventions have yielded benefits for student motivation to learn the course content, both in terms of perceived utility value and intrinsic value, especially for students who did not expect to do well (Hulleman \& Harackiwicz, 2009; Hulleman et al., 2010, 2017). This increased motivation through utility-value interventions has also been found to yield benefits in course performance (Harackiewicz et al., 2016).

\section{The Current Study}

The purpose of this study was to test the effectiveness of a utility-value intervention on student attitudes toward discussion boards. In the intervention in the current study, students watched a video on the benefits of discussion boards and wrote a short essay on the utility value of the task. This approach was based on findings that utility-value interventions were most effective when students received direct communication on utility value and then generated their own thoughts (Canning \& Harackiewicz, 2015). Writing was chosen as a means for generating utility value to be consistent with previous interventions (e.g., Hulleman \& Harackiewicz, 2009; Harackiewicz et al., 2016; see Priniski, Hecht, \& Harackiewicz, 2018). The intervention in the current study was at the beginning of the term so that students could begin with positive impressions of discussion boards, consistent with other work on in-class motivational interventions (Canning et al., 2018; McGinley \& Jones, 2014). However, the current intervention involved a single video and writing assignment, unlike other utility-value interventions that incorporated multiple assignments throughout the term (e.g., Harckiewicz et al., 2016; Kosovich, Hulleman, Phelps, \& Lee, 2019). The rationale for the difference in the intervention is that the students in the current study were directly informed about the benefits of a specific learning technique (i.e., discussion boards) only once because knowing the benefits of discussion boards was not a course objective. In contrast, utility-value interventions in previous studies were about value of the course content, which were logically the learning objectives in the courses. In studies in which students engaged in multiple writing assignments, they wrote about how the course content was useful or personally relevant as they were continually learning new content relevant to the utility-value intervention and had new topics to write about throughout the course. 
In this study, participants only learned about the discussion board benefits once and subsequently wrote about the benefits once. Furthermore, by having only one video and writing assignment, we were able to test if a brief intervention would be effective. A brief approach may be of interest to instructors who have limited time to cover necessary content.

This study builds on our previous work in which student attitudes toward face-to-face discussions were more positive after they engaged in a utility-value intervention regarding the benefits of group discussion compared to a control activity (Clinton \& Kelly, in-press). Given that students tend to have more negative attitudes toward discussion boards than face-to-face discussions (Jaggars \& Xu, 2016; Majid et al., 2015), specifically examining how a utility-value intervention could improve student attitudes toward discussion boards is a critically important issue. If effective, the developed intervention would provide online instructors with a brief, easyto-use, and evidence-based approach for enhancing student motivation toward discussion boards. In the present study, the following research questions were examined:

1) Would students who engaged in a utility-value intervention report discussion boards to be more useful (i.e., measure of utility-value) than students who completed a control activity? Based on previous research (Lazowski \& Hulleman, 2016), it was possible that the utility-value intervention would yield higher levels of reported usefulness (e.g., measure of utility-value) compared to the control condition. Further, although the intervention was not designed to directly address students' inherent enjoyment of discussion boards, it was possible that higher levels of utility-value would lead to greater appreciation of discussion boards, which would subsequently enhance levels of intrinsic value (Hulleman et al., 2017).

2) What would students in both the utility-value intervention and control conditions report regarding the usefulness (i.e., measure of utility-value), interest and enjoyment (i.e., measure of intrinsic value), and costs of discussion boards? This question was examined with open-ended items to assess how students varied in their opinions based on whether or not they received the utility-value intervention. In addition, examining these openended responses allowed for a deeper understanding of student attitudes toward discussion boards.

3) Were student attitudes toward discussion boards associated with course performance? It was possible that greater value of discussion boards would be associated with better 
performance in the course, both in terms of discussion board assignments and exams. In addition, if the intervention were effective in improving student attitudes towards discussion boards, this could carry over to better performance on both discussion board assignments and exams.

\section{Method}

\section{Context}

The current study involved one section of an online undergraduate Cognitive Psychology course (33 students; Spring 2018 semester) and two sections of an online undergraduate History and Systems of Psychology course (64 students total; Fall 2018 semester) at a mid-sized, Midwestern public university. Students in both courses were required to complete 4-5 discussion board assignments throughout the semester. For each assignment, the instructor provide a prompt to students that included 3-4 discussion questions based on course content. Each discussion board assignment required students to submit an initial post with responses to the discussion questions, as well as comments on the initial posts of 3-4 classmates. To earn full credit on the discussion board assignments, students were required to fulfill a number of grading criteria, including writing a substantive initial post that addressed all required questions, writing thoughtful comments on the initial posts of their peers, and adhering to guidelines related to timeliness and respectful discussion. The discussion board assignments counted toward $25 \%$ of the students' final grade in the courses. Following best practices in discussion boards, students had a rubric and guide regarding expectations and grading at the beginning of the term (Aloni \& Harrington, 2018).

Students took exams in both courses under the supervision of a proctor through the university's course learning management system (Blackboard). All exams included a combination of multiple choice, true/false, and matching questions and were worth between 75 100 points.

\section{Participants}

In both courses, all students were required to watch a video (intervention or control) and complete the quiz (intervention or control). In addition, all students were eligible to complete the pre- and post-intervention questionnaires. There were 97 students in the courses. One student was enrolled in both classes so only we only included the data from one class (the first chronologically). Of the eligible students, 65 completed the activities related to this study 
(syllabus quiz and post-intervention questionnaire, see Materials and Measures for details; see Table 1 for breakdown of students by condition by course). Of these 65 students, 10 reported they were men, 54 reported they were women, and 1 did not report gender. In terms of race, the majority identified as Caucasian (90\%) with 4\% identifying as African American, 3\% identifying as Hispanic, $1.4 \%$ identifying as Native American, and 1.4\% identifying as biracial (Note: Total does not add to $100 \%$ due to rounding). Students ranged in age from 20 to 53 years $(M=26.01$, $S D=9.15$ years). Prior to data collection, the authors obtained approval from the Institutional Review Board and an exempt protocol was granted.

\section{Materials and Measures}

Intervention and control materials. For the treatment condition, we designed the video to enhance utility value by presenting evidence on the usefulness of discussion boards for course and career goals. The video for the treatment condition presented the benefits of active learning for course performance (Freeman et al., 2014), explained that discussion boards are a method of active learning that have been shown to improve understanding of course content (Darabi et al., 2013; Green et al., 2014), prevent procrastination in online courses (Michinov et al., 2011), and develop virtual team skills that will help in future careers. Each of the benefits of discussion boards the video presented related to utility value in that they were either relevant for goals of doing well in the course or developing career skills. The video for the control condition only included information about the requirements for the discussion board assignments (e.g., the due dates and the need for initial posts and peer comments), how the assignments would be structured and graded, and the importance of respectful discussion.

After viewing either the treatment or control video, students in both conditions took a required quiz on the video. In both conditions, the quiz had the same 10 multiple-choice items that were based on the syllabus. The last item on the quiz was an essay that varied by condition. The purpose of this essay was for students to actively engage in the intervention. For the treatment condition, students answered the question "Based on the video you saw on discussion boards in this course, write 2 paragraphs on how discussion boards may be useful for learning course material or relevant to your life goals. Give at least 2 examples.” For the control condition, students answered the question "Based on the video you saw on discussion boards in this course, write 2 paragraphs on how discussion boards will be structured and graded in the course." 
Pre-intervention questionnaire. This questionnaire, which we adapted from Cantwell and Andrews (2002), was to assess student attitudes toward group discussions in general prior to the course. There were three scales: preference to work individually ( 7 items; Cronbach's $\alpha=$ $.70)$, preference to work in groups (6 items; Cronbach's $\alpha=.60)$, and discomfort with group discussion (4 items; Cronbach's $\alpha=.76$ ). We assessed student expectancy to do well in discussion boards through three items adapted from Hulleman and Harackiewicz (2009; Cronbach's $\alpha=.80)$. Participants also indicated how true of them the item "I am less motivated to learn from my peers" was as a measure of motivation for group learning. Participants indicated how true of them each of the items was on a five-point Likert scale ranging from "Not at all true of me" to "Very true of me." Student expectancy to do well in discussion boards was assessed through three items adapted from Hulleman and Harackiewicz (2009; Cronbach's $\alpha=$ .80). Participants rated their level of agreement on a seven-point Likert scale ranging from "Strongly Disagree" to "Strongly Agree." Participants responded to an item asking if they had used discussion boards in previous courses as a measure of previous experience and answered "yes" or "no." See Appendix for items.

Post-intervention questionnaire. This questionnaire, which was adapted from Hulleman and Harckiewicz (2009) and Hulleman and colleagues (2008), had scales for participants to report their perceptions of intrinsic value of discussion boards (six items; Cronbach's $\alpha=.91$ ) and the utility value of discussion boards (nine items; Cronbach's $\alpha=.91$ ). Participants indicated their level of agreement on a five-point Likert scale ranging from "Disagree Strongly" to "Agree Strongly." See Appendix for items measuring intrinsic and utility value. There were also three open-ended items regarding the perceived intrinsic value ("What is inherently interesting or enjoyable about the discussion boards?"), utility value ("How are discussion boards useful for you, now or in the future?"), and the potential costs of group discussions ("What are the costs or downsides of discussion boards in class?). Demographic items (e.g., gender, race, age) were at the end of the questionnaire. Note that more students in the control condition $(N=40)$ completed the post-intervention questionnaire than in the treatment condition $(N=25)$, which we address in the Limitations and Future Directions section.

To answer this research question, the authors identified themes to code in the open-ended items on intrinsic value, utility value, and costs through a content analysis in an inductive manner (similar to analyses in Barry, Murphy, \& Drew, 2015). A research assistant was given 
the codes and asked to code a subset of $50 \%$ of the responses. To calculate inter-rate reliability, Cohen's kappa coefficient ( $\kappa)$ was used. Cohen's kappa calculates the overall agreement among raters while accounting for chance agreement (Cohen, 1960). Perfect agreement between raters would be indicated with $\kappa=1$ and no agreement outside of what is expected by chance would be $\kappa=0$. Interrater reliability between the authors coding and the research assistants coding was good $(\kappa=.89)$. For all coding, the participant condition was masked.

\section{Procedure}

At the beginning of the semester, the instructor of the course asked students to complete a pre-intervention questionnaire about their attitudes toward individual or group work and awarded bonus points as an incentive for completion. The instructor randomly assigned students through the course learning management system to either view a video on the benefits on discussion boards (treatment) or how discussion boards would be graded (control). During the eighth week of the semester, the instructor asked students to complete a post-intervention questionnaire on the perceived value of discussion boards and awarded bonus points as an incentive for completion.

\section{Results}

To determine if there were a priori differences in preferences for group or individual work between the treatment and control conditions, we conducted three one-way analysis of variance tests with condition as the independent variable and with preference for individual work, preference for group work, and discomfort with group work as the dependent variables. There were no differences between the two conditions for preference for individual work, $F(1$, $59)=.30, p=.59$, Cohen's $d=.15$, preference for group work, $F(1,59)=.49, p=.49$, Cohen's $d$ $=.18$, discomfort with group work $F(1,59)=.001, p=.97$, Cohen's $d=.01$, or expectancy to do well in discussion boards, $F(1,59)=1.55, p=.22$, Cohen's $d=.33$. However, students in the treatment condition indicated they were less motivated to learn from their peers than did students in the control condition, $F(1,59)=6.76, p=.01$, Cohen's $d=.66$. Based on this, students in the treatment condition would likely have been less motivated to engage in discussion boards with peers than students in the control condition prior to the intervention. To compare previous experience with discussion boards by condition, we used binary logistic regression. The analysis of variance test would have been inappropriate because the dependent variable was a binary answer (yes or no) to whether they had had discussion boards in previous online courses. Answers were coded such that $1=$ yes and $0=$ no. The independent variable was condition 
(treatment or control). There were no significant differences in previous experience with discussion boards by condition, $\mathrm{B}=1.32, \mathrm{SE}=1.13$, Wald $=1.36, \operatorname{Exp}(\mathrm{B})=3.75, p=.24$. See Table 2 for means and standard deviations by condition.

\section{Do students who engaged in a utility-value intervention report discussion boards to be more useful (i.e., utility-value measure) than students who completed a control activity?}

To test the effects of the utility-value intervention on perceptions of discussion boards, we conducted a one-way analysis of variance test with condition as the independent variable and perceived utility value of discussion boards (items from the post-intervention questionnaire) as the dependent variable. There was an effect in which students in the treatment condition reported higher levels of perceived utility value than did participants in the control condition, $F(1,64)=$ $4.50, p=.04$, Cohen's $d=.53$. See Table 2 for means and standard deviations by condition. Do students who engaged in a utility-value intervention report discussion boards to be more inherently interesting or enjoyable (i.e., intrinsic value measure) than students who completed a control activity?

To test the effects of the intervention on intrinsic value of discussion boards, we conducted a one-way analysis of variance test with condition as the independent variable and perceived intrinsic value of discussion boards (from the post-intervention questionnaire) as the dependent variable. There was a not a reliable difference between students in the intervention condition and students in the control condition, $F(1,64)=3.34, p=.07$, Cohen's $d=.44$. See Table 2 for means and standard deviations by condition.

What do students in both the utility-value intervention and control conditions report to be the intrinsic value, utility-value, and costs of discussion boards?

Tables 3, 4, and 5 report the frequencies of the codes for intrinsic value, utility-value, and cost, respectively, with some students giving multiple answers. These frequencies represent the number of students who made a statement coded as a particular theme.

In terms of intrinsic value, students, especially those in the control condition, most commonly responded that a source of inherent interest and enjoyment for discussion boards was the opportunity to know other student perspectives and viewpoints. The second most common, particularly for students in the treatment condition who received the intervention, was getting to interact with their peers. Students also responded that getting to be creative and express themselves was a source of interest and enjoyment. Less common responses related to achieving 
course objectives (which would be more related to utility value), the content being discussed, and the real-life applications of the prompts. A minority of students indicated that they did not find anything enjoyable or interesting about the discussion boards.

For utility value, students in both conditions said they found discussion boards useful for understanding course objectives such as understanding the content and developing research skills. The second most common response was related to developing skills not directly related to the subject matter of the course, such as critical thinking and communication skills. Virtual teamwork skills, such as being able to interact with peers effectively through online communication skills, were also mentioned. Two less common responses were feeling connected to their peers and avoiding procrastination. Similar to intrinsic value, a sizeable minority reported they saw nothing useful or applicable to life goals in discussion boards.

For costs, there was a greater variety in response themes. Students reported the time involved with discussion boards as the most common downside to discussion boards. The second most common downside was related to perceived lack of engagement from peers with complaints that posts were superficial or that peers were rude. Also common was the perception that discussion boards were boring or not helpful for learning. Several students stated that they felt discussion boards were awkward and inherently inferior to face-to-face discussions. The ease of forgetting about online discussion deadlines was mentioned as an issue; however, this is likely common for most assignments for online courses. Finally, two students mentioned concerns about needing to censor themselves stating a fear that their response would be disseminated broadly across the internet. A small number of responses indicated that there were no perceived costs or downsides to discussion boards.

\section{Were student attitudes toward discussion boards associated with course performance?}

To address the fourth research question, we conducted Pearson product correlations between scores on the student attitude measures toward discussion boards (utility-value and intrinsic value) with percent performance on the discussion boards and exams in the courses (out of a possible 100 percent correct). There were no significant correlations between either utilityvalue or intrinsic value and discussion board performance, $r(65)=.00, p=.98$ and $r(65)=.03, p$ $=.79$, respectively. However, this may be due to the near ceiling performance on the discussion boards (mean performance of $95.83 \%$ ). In contrast, there were positive correlations between both 
utility-value and intrinsic value of discussion boards and exam performance, $r(65)=.26, p=.04$ and $r(65)=.33, p=.01$, respectively.

This fourth research question was further examined by conducting two one-way ANOVAs with condition as the independent variable and with discussion board performance and exam performance as dependent variables. Discussion board performance did not differ between condition, $F(1,64)=.03, p=.87, d=.02$. This is not surprising given the near ceiling performance on the discussion boards mentioned in the previous paragraph. Exam performance also did not differ between condition $F(1,64)=.02, p=.88, d=.08$, indicating that the positive association between the utility value of discussion boards and discussion board performance did not carry over to effects in learning performance.

\section{Discussion}

The purpose of this study was to examine student attitudes toward discussion boards, specifically whether a utility-value intervention could improve these attitudes. Based on the findings of this study, the utility-value intervention was effective, as students who received the intervention reported higher levels of utility-value than students who did not. However, there was not a reliable finding in terms of intrinsic value. Moreover, there was no effect of the intervention on discussion board performance or exam performance.

This intervention is consistent with advice to overcome student resistance to active learning by explaining the value of active learning instruction (Finelli et al., 2018). As an active learning technique, discussion boards appear to have numerous benefits for learning and engagement (Cho \& Tobias, 2016; Green et al., 2014; Kent et al., 2016; Wei et al., 2015). However, students tend to have negative attitudes toward discussion boards, perhaps because they do not appreciate the usefulness of discussion boards (Majid et al., 2015). This intervention was designed to improve student attitudes by having them directly learn about the benefits in a video presentation, then self-generate a response on how discussion boards are useful. Based on the perceived utility-value scores, the intervention was effective. Therefore, the intervention described in this study provides instructors with a simple, evidence-based method to improve student attitudes toward discussion boards.

The intervention was grounded in the expectancy-value theory of motivation (Wigfield \& Eccles, 2002) and based on previous work on utility-value interventions (Canning \& Harackiewicz, 2015; Hulleman \& Harackiewicz, 2009). This study expands the application of 
utility-value interventions to a specific type of learning activity whereas the bulk of the previous work on utility-value interventions addressed student attitudes toward course content (Canning \& Harackiewicz, 2015; Hulleman \& Harackiewicz, 2009; Hulleman et al., 2010; Hulleman et al., 2017). Because the intervention was focused on addressing attitudes toward a specific learning technique rather than content being learned throughout a term, this intervention differed from previous interventions as it only had a single, brief writing assignment (two paragraphs required) as opposed to multiple longer writing assignments (e.g., one-to-two full pages required; e.g., Harackiewicz et al., 2016; Kosovich et al. 2019).

The benefits of this intervention were limited to utility value - there was not a reliable benefit for intrinsic value. This differs from findings from other studies in which the enhanced utility-value carried over to a benefit of intrinsic value as well (Hulleman \& Harackiewicz, 2009; Hulleman et al., 2010). That is, students who received the intervention reported that discussion boards were more useful and personally important than did students in the control, but there was no reliable difference for how interesting and enjoyable discussion boards were between the students in the two conditions. Intrinsic value is considered more difficult to manipulate than utility-value as intrinsic value comes from within an individual, whereas utility value is thought to be developed through external influences (Harackiewicz et al., 2016). The intervention may have not been sufficiently strong enough to affect intrinsic value as it was only one video and one short writing assignment as opposed to multiple writing assignments throughout the semester (Hulleman \& Harackiewicz, 2009; Hulleman et al., 2017). Alternatively, the lack of a significant benefit of the intervention on intrinsic value may be just be due to a lack of statistical power coupled with less motivation to learn from peers prior to the intervention by students in the treatment condition compared to the control.

Based on student responses to open-ended items, there are many reasons why online discussion boards are considered to be interesting or useful. Students expressed an appreciation for the opportunity to connect with other students, particularly in an online course. In addition, they liked being able to share their personal viewpoints and read the viewpoints of others. In terms of usefulness, students in both conditions perceived discussion boards as helping them achieve course objectives and develop critical thinking and communication skills.

The student responses regarding the costs or downsides of discussion boards may be useful for instructors to consider. For example, many students indicated that discussion boards 
were time consuming; therefore, explaining to students how discussion boards are worth the time involved may help ameliorate attitudes. Also, issues with perceived lack of peer engagement or rudeness could be addressed with clear expectations for discussion board participants and grading with feedback on how to have more engaging posts and responses. Moreover, such feedback would provide for clear and structured evaluation, which is recommended to address student resistance to active learning (Finelli et al., 2018) and best practices in discussion boards (Aloni \& Harrington, 2018).

The utility-value intervention on the course activity of discussion boards did not affect learning in the course as assessed by exam performance in this study. This is similar to previous interventions in psychology courses incorporating expectancy-value theory that have yielded benefits related to student attitudes toward the course, but not course performance (Hulleman et al., 2010; McGinley \& Jones, 2014). In contrast, a different utility intervention that had two intervention doses and a larger sample found a benefit for grades that was primarily driven by benefits for lower-performing male students (Hulleman et al., 2017). It is possible that there were moderators unrelated to motivation that affected grades that were not examined in this study, such as prior academic background. Furthermore, without knowing the prior academic background of the students, it is possible students in the control group happened to have stronger backgrounds that could mitigate any potential grade benefits of the intervention. Moreover, if the benefits of utility-value interventions on course performance are greater for male students than female students (e.g., Hulleman et al., 2017; Rozek, Hyde, Svoboda, Hulleman, \& Harackiewicz, 2015), we would not expect to see an effect on course performance in this study with a predominantly female sample. There were no associations between student attitudes toward online discussion or the intervention on discussion board performance. However, students generally did quite well on the discussion boards so there was likely a ceiling effect.

Although there was no effect of the intervention on performance, there was a positive association between exam performance and student attitudes toward the usefulness of discussion boards (utility value) and the interest and enjoyment of discussion boards (intrinsic value). This finding converges with others on utility-value measures related to the content of a course and course performance (Hulleman et al. 2008; Hulleman \& Harackiewicz, 2009; Hulleman et al., 2010; Hulleman et al., 2017) as well as findings that student acceptance towards active learning is positively correlated with course performance (Cavanagh et al., 2016). Such findings support 
the need to address student attitudes toward instructional practices as they may be related to performance.

\section{Limitations and Future Directions}

There are limitations in the study that should be noted. This study tested the main effects of a brief motivational intervention to encourage students to view discussion boards as useful and personally relevant in only two undergraduate courses at just one institution. These courses were upper level and most of the students were majoring in field; therefore, they may have had more inherent motivation to engage in the course. Future research could expand on this work using introductory-level courses with students from a variety of disciplinary backgrounds.

There was response bias in the sample with more control students completing the questionnaire than did students who received the intervention. This difference is only noted in one of the courses (History and Systems) with the other course (Cognitive Psychology) having an even distribution of student responses in condition. One reason for this could be that students in the control condition were more inclined than students who received the intervention to take advantage of an opportunity to express their dislike of discussion boards in hopes the instructor would discontinue discussion boards. Students who received the intervention may have had less strong opinions and have been less inclined to respond to the questionnaire. History and Systems is a required course whereas Cognitive Psychology is an elective. It is possible that potential dislike of discussions in the control group may have been more intense for the required course prompting a differential response rate. Another possible reason is that the required assignment for the intervention condition (writing about how discussion boards were useful for goals and personally relevant) required more thought and effort than the assignment for the control (summarizing how discussion boards would be graded). Because of the different levels of effort involved, students in the treatment group may have been less inclined to complete the assignment compared to students in the control group. However, these explanations are based solely on conjecture; we do not have data to support them.

The discussion board activity and performance for this study was limited to the grades students received for their participation. Future research studies could examine relationships between student attitudes towards online discussion and discussion board activity with more precise learning analytic data such as time spent on the board. Such data were not available through the learning management system used in this study. 


\section{Conclusion}

Some students harbor negative opinions about discussion boards. This study provided a theoretically-grounded and brief approach to improving student attitudes toward discussion boards by emphasizing their usefulness in achieving course performance and career goals. Instructors can use this to encourage students to have more positive attitudes about discussion boards. In addition, the student responses to open-ended items provide an understanding of how students perceive the value and costs of discussion boards to inform instructional practices and future research. 


\section{References}

Aloni, M., \& Harrington, C. (2018). Research based practices for improving the effectiveness of asynchronous online discussion boards. Scholarship of Teaching and Learning in Psychology, 4(4), 271-289. doi: 10.1037/st10000121

Barron K. E., Hulleman C.S. The expectancy-value-cost model of motivation J.D. Wright (Ed.), International encyclopedia of the social and behavioral sciences ( $\left.2^{\text {nd }} \mathrm{ed}.\right)$, Elsevier Ltd, Oxford (2015)

Barry, S., Murphy, K., \& Drew, S. (2015). From deconstructive misalignment to constructive alignment: Exploring student uses of mobile technologies in university classrooms. Computers \& Education, 81, $202-210$. http://dx.doi.org/10.1016/j.compedu.2014.10.014

Canning, E., Harackiewicz, J., Priniski, S., Hecht, C., Tibbetts, Y., \& Hyde, J. (2018). Improving performance and retention in introductory biology with a utility-value intervention. Journal Educational Psychology, 110(6), 834-849. doi: 10.1037/edu0000244

Cantwell, R. H., \& Andrews, B. (2002). Cognitive and psychological factors underlying secondary school students' feelings toward group work. Educational Psychology, 22(1), 75 - 91. doi: 10.1080/01443410120101260

Cavanagh, A. J., Aragón, O. R., Chen, X., Couch, B. A., Durham, M. F., Bobrownnicki, A., \& Graham, M. J. (2016). Student buy-in to active learning in a college science course. $C B E$ Life Sciences Education, 15(4), ar76.

Cavanaugh, J. K., \& Jacquemin, S. J. (2015). A large sample comparison of grade based student learning outcomes in online vs. face-to-face courses. Online Learning, 19(2), n2. doi: 10.24059/olj.v19i2.454

Cho, M. H., \& Tobias, S. (2016). Should instructors require discussion in online courses? Effects of online discussion on community of inquiry, learner time, satisfaction, and achievement. The International Review of Research in Open and Distributed Learning, 17(2). doi: 10.19173/irrodl.v17i2.2342

Clinton, V. \& Kelly, A. E. (in-press). Student attitudes toward group discussions. Active Learning in Higher Education. doi: 10.1177/1469787417740277 
Clinton, V. \& Wilson, N. (in-press). More than chalkboards: classroom spaces and collaborative learning attitudes. Learning Environments Research. doi: 10.1007/s109840019-09287-w

Cohen, J.A. (1960). Coefficent of agreement for nominal scales. Educational and Psychological Measurement, 20, 37-46.

Daouk, Z., Bahous, R., \& Bacha, N.N. (2016). Perceptions on the effectiveness of active learning strategies. Journal of Applied Research in Higher Education, 8(3), 360-375. doi: 10.1108/JARHE-05-2015-0037

Darabi, A., Liang, X., Suryavanshi, R., \& Yurekli, H. (2013). Effectiveness of online discussion strategies: A meta-analysis. American Journal of Distance Education, 27(4), 228 - 241. doi: 10.1080/08923647.2013.837651

Davies, J., \& Graff, M. (2005). Performance in e-learning: online participation and student grades. British Journal of Educational Technology, 36(4), 657-663. doi: 10.1111/j.14678535.2005.00542.x

Dennen, V.P. (2008). Pedagogical lurking: Student engagement in non-posting discussion behavior. Computers in Human Behavior, 24(4), 1624-1633. doi: 10.1016/j.chb.2007.06.003

Dietz-Uhler, B., \& Lanter, J. R. (2012). Perceptions of group-led discussion boards: The benefits of cooperative learning. Journal of Educational Technology Systems, 40(4), 381-388. doi: 10.2190/et.40.4.d

Eccles, J., Adler, T. F., Futterman, R., Goff, S. B., Kaczala, C. M., Meece, J., \& Midgley, C. (1983). Expectancies, values, and academic behaviors. In J. T. Spence (Ed.), Achievement and achievement motives, San Francisco: W. H. Freeman.

Eccles, J. S., \& Wigfield, A. (2002). Motivational beliefs, values, and goals. Annual Review of Psychology, 53, 109 - 132. doi: 10.1146/annurev.psych.53.100901.135153

Eccles, J. S. (2005). Subjective task values and the Eccles et al. model of achievement-related choices. In A. J. Elliot \& C. S. Dweck (Eds.), Handbook of competence and motivation (pp. 105-121). New York, NY: Guilford.

Freeman, S., Eddy, S. L., McDonough, M., Smith, M. K., Okoroafor, N., Jordt, H., \& Wenderoth, M. P. (2014). Active learning increases student performance in science, engineering, and mathematics. Proceedings of the National Academy of Sciences, USA, 111, 8410 - 8414. doi: 10.3410/f.718384493.793495199 
Finelli, C.J., Nguyen, K., DeMonbrun, M., Borrego, M., Price, M., Husman, J., ... \& Waters, C.K. (2018). Reducing student resistance to active learning: Strategies for instructors. Journal of College Science Teaching, 47(5), 80-91.

Flake, J. K., Barron, K. E., Hulleman, C., McCoach, B. D., \& Welsh, M. E. (2015). Measuring Cost: The forgotten component of expectancy-value theory. Contemporary Educational Psychology, 41, 232-244. doi: 10.1016/j.cedpsych.2015.03.002

Gayman, C. M., Hammonds, F., \& Rost, K. A. (2018). Interteaching in an asynchronous online class. Scholarship of Teaching and Learning in Psychology, 4(4), 231-242. doi: $10.1037 /$ st10000126

Green, R. A., Farchione, D., Hughes, D. L., \& Chan, S. P. (2014). Participation in asynchronous online discussion forums does improve student learning of gross anatomy. Anatomical Sciences Education, 7(1), 71-76. doi: 10.1002/ase.1376

Harackiewicz, J. M., Canning, E. A., Tibbetts, Y., Priniski, S. J., \& Hyde, J. S. (2016). Closing achievement gaps with a utility-value intervention: Disentangling race and social class. Journal of Personality and Social Psychology, 111(5), 745-765. doi: $10.1037 / \mathrm{pspp} 0000075$

Hulleman, C. S., Durik, A. M., Schweigert, S. B., \& Harackiewicz, J. M. (2008). Task values, achievement goals, and interest: An integrative analysis. Journal of Educational Psychology, 100(2), 398-416. doi: 10.1037\%2F0022-0663.100.2.398

Hulleman, C. S., Godes, O., Hendricks, B. L., \& Harackiewicz, J. M. (2010). Enhancing interest and performance with a utility value intervention. Journal of Educational Psychology, 102(4), 880-895. doi: 10.1037/a0019506

Hulleman, C. S., \& Harackiewicz, J. M. (2009). Promoting interest and performance in high school science classes. Science, 326(5958), 1410-1412. doi: 10.1126/science.1177067

Hulleman, C. S., Kosovich, J. J., Barron, K. E., \& Daniel, D. B. (2017). Making connections: Replicating and extending the utility value intervention in the classroom. Journal of Educational Psychology, 109(3), 387-404. doi: 10.1037/edu0000146

Hurt, N. E.; Moss, G. S., Bradley, C.L., Larson, L.R., Lovelace, M., Prevost, L.B., Riley, N., Domizi, D., \& Camus, M.S. (2012) “The 'Facebook' Effect: College students' perceptions of discussion boards in the age of social networking," International Journal 
for the Scholarship of Teaching and Learning: 6(2), Article 10. Available at: https://doi.org/10.20429/ijsotl.2012.060210

Jaggars, S. S., \& Xu, D. (2016). How do online course design features influence student performance? Computers \& Education, 95, 270-284. doi:10.1016/j.compedu.2016.01.014

Jiang, Y., Rosenzweig, E. Q., \& Gaspard, H. (2018). An expectancy-value-cost approach in predicting adolescent students' academic motivation and achievement. Contemporary Educational Psychology, 54, 139-152. doi: 10.1016/j.cedpsych.2018.06.005

Johnson, D., \& Palmer, C. C. (2015). Comparing student assessments and perceptions of online and face-to-face versions of an introductory linguistics course. Online Learning, 19(2), n2. doi: 10.24059/olj.v19i2.449

Joksimović, S., Gašević, D., Kovanović, V., Riecke, B. E., \& Hatala, M. (2015). Social presence in discussion boards as a process predictor of academic performance. Journal of Computer Assisted Learning, 31(6), 638-654. doi: 10.1111/jcal.12107

Kauffman, H. (2015). A review of predictive factors of student success in and satisfaction with online learning. Research in Learning Technology, 23, 26507. doi: 10.3402/rlt.v23.26507

Kent, C., Laslo, E., \& Rafaeli, S. (2016). Interactivity in discussion boards and learning outcomes. Computers \& Education, 97, 116-128. doi: 10.1016/j.compedu.2016.03.002

Kosovich, J. J., Hulleman, C. S., Phelps, J., \& Lee, M. (2019). Improving algebra success with a utility-value intervention. Journal of Developmental Education, 42(2), 2-10.

Kurucay, M., \& Inan, F. A. (2017). Examining the effects of learner-learner interactions on satisfaction and learning in an online undergraduate course. Computers \& Education, 115, 20-37. doi: 10.1016/j.compedu.2017.06.010

Lazowski, R. A., \& Hulleman, C. S. (2016). Motivation interventions in education: A metaanalytic review. Review of Educational Research, 86(2), 602-640. doi: $10.3102 / 0034654315617832$

Liu, S. Y., Gomez, J., \& Yen, C. (2009). Community college online course retention and final grade: Predictability of social presence. Journal of Interactive Online Learning, 8(2), 165 - 182. doi: 10.2190/ec.41.3.e

Lobo, G. (2017). Active learning interventions and student perceptions. Journal of Applied Research in Higher Education, 9(3), 465-473. doi: 10.1108/jarhe-09-2016-0061

Majid, S., Idio, C. D., Liang, S., \& Zhang, W. (2015). Preferences and motivating factors for 
knowledge sharing by students. Journal of Information \& Knowledge Management, 14(1), 1550004. doi: 10.1142/s0219649215500045

McGinley, J. J., \& Jones, B. D. (2014). A Brief Instructional Intervention to Increase Students' Motivation on the First Day of Class. Teaching of Psychology, 41(2), 158-162. Https://doi.org/10.1177/0098628314530350

Michinov, N., Brunot, S., Le Bohec, O., Juhel, J., \& Delaval, M. (2011). Procrastination, participation, and performance in online learning environments. Computers \& Education, 56(1), 243-252. doi: 10.1016/j.compedu.2010.07.025

Murphy, C. A., \& Stewart, J. C. (2017). On-campus students taking online courses: Factors associated with unsuccessful course completion. The Internet and Higher Education, 34, 1-9. doi: 10.1016/j.iheduc.2017.03.001

Nguyen, K., Husman, J., Waters, C., Henderson, C., Finelli, C. J., Demonbrun, M., ... \& Borrego, M. (2017). Students' expectations, types of instruction, and instructor strategies predicting student response to active learning. The International Journal of Engineering and Education, 33(1), 2-18.

Ortagus. J. C. (2017). From the periphery to prominence: An examination of the changing profile of online students in American higher education. The Internet and Higher Education, 32, 47 - 57. doi: 10.1016/j.iheduc.2016.09.002

Ortagus, J. C. (2018). National evidence of the impact of first-year online enrollment on postsecondary students' long-term academic outcomes. Research in Higher Education, 124. doi: 10.1007/s11162-018-9495-1

Poll, K., Widen, J., \& Weller, S. (2014). Six instructional best practices for online engagement and retention. Journal of Online Doctoral Education, 1(1), 56 - 72.

Priniski, S. J., Hecht, C.A., \& Harackiewicz, J. M. (2018). Making learning personally meaningful: A new framework for relevance research. The Journal of Experimental Education, 86(1), 11-29.

Querol, B. I. D., Rosales, R., \& Soldner, J. L. (2015). A comprehensive review of interteaching and its impact on student learning and satisfaction. Scholarship of Teaching and Learning in Psychology, 1(4), 390-411. http://dx.doi.org/10.1037/st10000048

Rockinson-Szapkiw, A., Wendt, J., Whighting, M., \& Nisbet, D. (2016). The predictive 
relationship among the community of inquiry framework, perceived learning and online, and graduate students' course grades in online synchronous and asynchronous courses. The International Review of Research in Open and Distributed Learning, 17(3). doi:10.19173/irrodl.v17i3.2203

Rozek, C. S., Hyde, J. S., Svoboda, R. C., Hulleman, C. S., \& Harackiewicz, J. M. (2015). Gender differences in the effects of a utility-value intervention to help parents motivate adolescents in mathematics and science. Journal of Educational Psychology, 107(1), 195. doi: $10.1037 / \mathrm{a} 0036981$

Saville, B. K., Zinn, T. E., Neef, N. A., Norman, R. V., \& Ferreri, S. J. (2006). A comparison of interteaching and lecture in the college classroom. Journal of Applied Behavior Analysis, 39(1), 49-61. doi: 10.1901/jaba.2006.42-05

Shekhar, P., Prince, M., Finelli, C., Demonbrun, M., \& Waters, C. (2018). Integrating quantitative and qualitative research methods to examine student resistance to active learning. European Journal of Engineering Education, 1-13. doi:10.1080/03043797.2018.1438988

Tsang, A., \& Harris, D. M. (2016). Faculty and second-year medical student perceptions of active learning in an integrated curriculum. Advances in Physiology Education, 40(4), 446-453. doi: 10.1152/advan.00079.2016

Tello, S. F. (2007). An analysis of student persistence in online education. International Journal of Information and Communication Technology Education, 3(3), 47 - 62. doi:10.4018/jicte.2007070105

Uijl, S., Filius, R., \& Ten Cate, O. (2017). Student interaction in small private online courses. Medical Science Educator, 27(2), 237-242. doi:10.1007/s40670-017-0380-x

Wei, H. C., Peng, H., \& Chou, C. (2015). Can more interactivity improve learning achievement in an online course? Effects of college students' perception and actual use of a coursemanagement system on their learning achievement. Computers \& Education, 83, 10-21. doi: 10.1016/j.compedu.2014.12.013

Wigfield, A., \& Eccles, J. S. (2000). Expectancy-value theory of achievement motivation. Contemporary Educational Psychology, 25(1), 68 - 81. doi:10.1006/ceps.1999.1015 
Zayac, R. M., \& Paulk, A. L. (2014). Interteaching: Its effects on exam scores in a compressed schedule format. Journal of the Scholarship of Teaching and Learning, 14, 1-12. 10.14434/josotl.v14i1.3649 
Table 1

Students in each condition in each course

\begin{tabular}{lll}
\hline & Control & Treatment \\
\hline Cognitive Psychology & 12 & 12 \\
\hline History and Systems & 28 & 13 \\
\hline
\end{tabular}


Table 2

Means and Standard Deviations of Measures by Condition

\begin{tabular}{lcc}
\hline & $\begin{array}{l}\text { Control } \\
M(S D)\end{array}$ & $\begin{array}{c}\text { Treatment } \\
M(S D)\end{array}$ \\
\hline Construct & Pre-intervention Questionnaire \\
\hline $\begin{array}{l}\text { Expectancy to do well in } \\
\text { discussion boards }\end{array}$ & $5.75(1.05)$ & $6.10(1.10)$ \\
\hline Preference for individual work & $2.44(.63)$ & $2.53(.62)$ \\
\hline Preference for group work & $3.04(.76)$ & $2.91(.66)$ \\
\hline Discomfort with group work & $2.43(.83)$ & $2.43(.94)$ \\
\hline $\begin{array}{l}\text { Less motivated to learn from } \\
\text { peers }\end{array}$ & $1.97(1.16)$ & $2.74(1.18)^{*}$ \\
\hline $\begin{array}{l}\text { Previous experience with } \\
\text { discussion boards in online }\end{array}$ & $.85(.36)$ & $.95(.21)$ \\
courses & & \\
\hline Intrinsic value & Post-intervention Questionnaire \\
\hline Utility value & $2.66(1.00)$ & $3.12(.95)$ \\
\hline & $3.02(.85)$ & $3.51(1.00)^{*}$ \\
\hline Discussion board performance & $95.72(6.11)$ & $95.86(9.07)$ \\
\hline Exam performance & $80.68(11.34)$ & $79.75(13.40)$ \\
\hline
\end{tabular}

Note: $N=61$ pre-intervention, $N=65$ post-intervention. Expectancy was on a 1-7 scale, preferences, motivation, intrinsic value, and utility value were on 1-5 scales. Discussion board and exam performance was percentage of points possible earned (0-100 scale).

${ }^{1}$ Answers were coded as $1=$ yes and $0=$ no

$* p<.05$ 
Table 3

Examples and frequency of themes by condition for responses to the intrinsic value of online discussion boards

\begin{tabular}{|c|c|c|c|c|}
\hline & Example & Treatment & Control & Total \\
\hline $\begin{array}{l}\text { Other } \\
\text { perspectives/viewpoints }\end{array}$ & $\begin{array}{l}\text { "Different personal examples are fun. } \\
\text { Helps me see things in a new way." }\end{array}$ & 9 & 24 & 33 \\
\hline $\begin{array}{l}\text { Interacting with and } \\
\text { getting feedback from } \\
\text { peers }\end{array}$ & $\begin{array}{l}\text { "I think it is fun to be able to } \\
\text { comment back and forth with other } \\
\text { individuals." }\end{array}$ & 9 & 8 & 17 \\
\hline $\begin{array}{l}\text { Opportunity to be } \\
\text { creative and express } \\
\text { opinions }\end{array}$ & $\begin{array}{l}\text { "I like being able to share my own } \\
\text { opinions and thoughts on different } \\
\text { topics." }\end{array}$ & 4 & 6 & 10 \\
\hline $\begin{array}{l}\text { Better understanding } \\
\text { the material/develop } \\
\text { critical thinking skills }\end{array}$ & $\begin{array}{l}\text { "They allow you to critically think } \\
\text { about the material and read about how } \\
\text { others interpreted the material." }\end{array}$ & 3 & 2 & 5 \\
\hline $\begin{array}{l}\text { The content for } \\
\text { discussion }\end{array}$ & $\begin{array}{l}\text { "The reading of the material prior to } \\
\text { answering the discussion board } \\
\text { questions." }\end{array}$ & 1 & 2 & 3 \\
\hline $\begin{array}{l}\text { Prompts relate to real } \\
\text { life }\end{array}$ & $\begin{array}{l}\text { "I enjoy discussing the aspects of } \\
\text { what we are learning about and how it } \\
\text { relates to daily life." }\end{array}$ & 2 & 1 & 3 \\
\hline Nothing & $\begin{array}{l}\text { "I don't find anything interesting or } \\
\text { enjoyable about discussion boards." }\end{array}$ & 3 & 5 & 8 \\
\hline
\end{tabular}

Note: $N=65$ 
Table 4

Examples and frequency of themes by condition for responses to the utility value of online discussion boards

\begin{tabular}{|c|c|c|c|c|}
\hline & Example & Treatment & Control & Total \\
\hline $\begin{array}{l}\text { Better understanding } \\
\text { the course objectives }\end{array}$ & $\begin{array}{l}\text { "The discussion boards were useful } \\
\text { for me in that they helped me apply } \\
\text { the concepts we learned about, and } \\
\text { explaining the concepts also helped } \\
\text { me learn them better." }\end{array}$ & 10 & 16 & 26 \\
\hline $\begin{array}{l}\text { Critical thinking and } \\
\text { communication skills }\end{array}$ & $\begin{array}{l}\text { "I believe the discussion boards help } \\
\text { hone my written communication as } \\
\text { well as my critical thinking skills. } \\
\text { These skills are imperative for my } \\
\text { future, especially future employment } \\
\text { and graduate school." }\end{array}$ & 8 & 9 & 17 \\
\hline Virtual teamwork skills & $\begin{array}{l}\text { "They strengthen online interpersonal } \\
\text { skills which are useful in academics } \\
\text { and in my future career." }\end{array}$ & 4 & 6 & 10 \\
\hline $\begin{array}{l}\text { Connections with other } \\
\text { students/course } \\
\text { engagement }\end{array}$ & $\begin{array}{l}\text { "It makes me feel connected even } \\
\text { though I am across the country to the } \\
\text { students and my university." }\end{array}$ & 2 & 2 & 4 \\
\hline Avoid procrastination & $\begin{array}{l}\text { "Staying up to date on the current } \\
\text { material." }\end{array}$ & 0 & 2 & 2 \\
\hline Nothing & "I don't think they are useful." & 3 & 6 & 9 \\
\hline
\end{tabular}

Note: $N=65$ 


\section{Table 5}

Examples and frequency of themes by condition for responses to the costs of online discussion boards

\begin{tabular}{|c|c|c|c|c|}
\hline & Example & Treatment & Control & Total \\
\hline Time consuming & $\begin{array}{l}\text { "They are a waste of time as they } \\
\text { require students to spend time that } \\
\text { could be used studying the material } \\
\text { writing posts and responding to others } \\
\text { posts" }\end{array}$ & 10 & 15 & 25 \\
\hline $\begin{array}{l}\text { Peers' lack of } \\
\text { engagement and } \\
\text { effort/rudeness }\end{array}$ & $\begin{array}{l}\text { "It can be annoying when you put in a } \\
\text { lot of effort into your board and you } \\
\text { scroll past someone else who only } \\
\text { writes a sentence or two for each } \\
\text { answer." }\end{array}$ & 8 & 10 & 18 \\
\hline $\begin{array}{l}\text { Boring/not helpful for } \\
\text { learning }\end{array}$ & $\begin{array}{l}\text { "One downside I have found from } \\
\text { discussion boards is the repetitive } \\
\text { summarizing of the same information. } \\
\text { Some discussion threads and } \\
\text { comments are the same exact thing } \\
\text { over and over. This makes } \\
\text { contributing to the discussion or } \\
\text { coming up with a comment difficult } \\
\text { when there is no new information to } \\
\text { "spark an idea" from." }\end{array}$ & 5 & 8 & 13 \\
\hline $\begin{array}{l}\text { Difficult to } \\
\text { communicate } \\
\text { online/inferior to face- } \\
\text { to-face discussions }\end{array}$ & $\begin{array}{l}\text { "It is difficult to go back and forth } \\
\text { with one person if you are trying to } \\
\text { discuss what they said (it would be } \\
\text { easier in a face-to-face conversation, } \\
\text { discussion boards are not the most } \\
\text { conducive to this specific } \\
\text { experience.)" }\end{array}$ & 3 & 8 & 11 \\
\hline Easy to forget & $\begin{array}{l}\text { "The costs of a discussion board are if } \\
\text { you forget that you need to post it by } \\
\text { a certain time." }\end{array}$ & 0 & 3 & 3 \\
\hline $\begin{array}{l}\text { Feeling a need to } \\
\text { censor oneself }\end{array}$ & $\begin{array}{l}\text { "Some people may be afraid to have } \\
\text { an unfavorable opinion that gets } \\
\text { spread around the internet and } \\
\text { connected back to that person." }\end{array}$ & 1 & 1 & 2 \\
\hline None & "I do not believe there is a downside." & 2 & 3 & 5 \\
\hline
\end{tabular}

Note: $N=65$ 